\title{
PENINGKATAN KOMPETENSI PENDIDIK DALAM PENYUSUNAN MODUL BAHAN AJAR DI YAYASAN ISKANDARIYAH TANGERANG SELATAN
}

\author{
${ }^{1)}$ Edi Junaedi, ${ }^{2)}$ Turkamun, ${ }^{3)}$ Deni Darmawan, ${ }^{4)}$ Sapto Hadi Imambachri, dan \\ ${ }^{5)}$ Ismul Bathni Sumadikarta \\ Universitas Pamulang \\ dosen00809@unpam.ac.id
}

\begin{abstract}
The teaching materials module is one consequence of the implementation of the CompetencyBased Education Unit Level Curriculum in schools. The competency approach requires the use of teaching materials modules in the implementation of learning. This teaching material module can assist schools in realizing quality learning and having uniformity in the delivery of subject matter from educators to all students. The application of the teaching material module can condition learning activities to be better, planned, directed, independent, complete and with optimal results in accordance with the initial target and according to the expectations of the school/foundation. Teaching Materials Module is material that is systematically arranged in language that is easily understood by students according to their age and level of knowledge, with the aim that they (students/students) can study independently even with minimal guidance from educators (Andi Prastowo, 2012: 106). The module is a program package that is structured and designed in such a way as a material and reference for student learning and as a teaching reference for all educators. With the Teaching Materials Module, it is hoped that the student's learning process can be independent and also to help students more easily master their learning objectives. Therefore, students can learn according to their respective absorption and capture power. Our intention and purpose of conducting PKM (Community Service) by providing guidance on the preparation of Teaching Materials at the Iskandariyah Ciputat Foundation is based on our desire to play an active role in building a strong and good quality education so that it can provide satisfaction for teachers, students, staff, parents, and the surrounding community in general, whose ultimate goal is that the Iskandariyah Ciputat Education Foundation, South Tangerang, can improve the quality of the learning process, improve the quality of schools in general and be able to produce quality graduates in welcoming the world of work.
\end{abstract}

\begin{abstract}
ABSTRAK
Modul bahan ajar adalah salah satu konsekuensi diterapkannya Kurikulum Tingkat Satuan Pendidiakn Berbasis Komptensi di sekolah. Pendekatan kompetensi mempersyaratkan penggunaan modul bahan ajar dalam pelaksanaan pembelajarannya. Modul bahan ajar ini dapat membantu sekolah dalam mewujudkan pembelajaran yang berkualitas dan memiliki keseragaman dalam penyampaian materi pelajaran dari tenaga pendidik kepada seluruh siswa/siswinya. Penerapan modul bahan ajar dapat mengkondisikan kegiatan pembelajaran lebih baik, terencana, terarah, mandiri, tuntas dan dengan hasil (output) yang optimal sesuai dengan target awal dan sesuai harapan pihak sekolah/yayasan. Modul Bahan Ajar merupakan materi yang disusun secara sistematik dengan bahasa yang mudah dipahami oleh siswa sesuai usia dan tingkat pengetahuan mereka, dengan tujuan agar mereka (siswa/siswi) dapat belajar secara mandiri walaupun dengan tingkat bimbingan yang minim dari pendidik (Andi Prastowo, 2012 : 106). Modul merupakan paket program yang disusun dan didesain sedemikian rupa sebagai bahan dan acuan belajar siswa dan sebagai acuan mengajar semua tenaga pendidik.
\end{abstract}


Dengan adanya Modul Bahan Ajar diharapkan proses belajar siswa bisa mandiri dan juga untuk membantu siwa lebih mudah menguasai tujuan belajarnya. Oleh karena itu, siswa dapat belajar sesuai dengan daya serap dan daya tangkap masing-masing. Maksud dan tujuan kami melakukan PKM (Pengabdian Kepada Masyarakat) dengan memberikan pembinaan tentang penyusunan Bahan Ajar di Yayasan Iskandariyah Ciputat ini didasari oleh keinginan kami untuk ikut berperan aktif dalam membangun kualitas pendidikan yang kuat dan baik sehingga dapat memberikan kepuasan bagi guru, siswa/siswi, staf, orang tua siswa, serta masyarakat sekitar pada umumnya, yang tujuan akhirnya agar Yayasan Pendidikan Iskandariyah Ciputat Tangerang Selatan dapat meningkatkan mutu proses pembelajaran, meningkatkan mutu sekolah secara umum dan mampu menghasilkan lulusan yang berkualitas dalam menyongsong dunia kerja.

\section{PENDAHULUAN}

Kita ketahui bersama bahwa banyak sekali media, alat atau fasilitas kelengkapan belajar yang harus dimiliki oleh setiap yayasana pendidikan agar dapat menghasilkan lulusan dengan kualitas unggul dan mumpuni. Salah satu media yang harus dimiliki oleh yayasan pendidikan dalam rangka meningkatkan efektifitas proses belajar mengajar adalah Modul Bahan Ajar. Seberapa pentingnya bahan ajar bagi dunia pendidikan? Jelas sangat penting. Pentingya

Modul Bahan Ajar bagi setiap lembaga pendidikan adalah suatu keniscayaan. Karena tanpa modul bahan ajar yang baik, lengkap dan komprehensip rasanya akan sulit tercapai efektifitas dalam proses belajar mengajar. Tentunya modul bahan ajar harus disusun sedemikian rupa yang merepresentasikan Satuan Acara Pembelajaran sesuai kurikulum yang berlaku dan harus memuat materi yang lengkap sesuai yang diamantkan oleh kurikulum. Saat ini masih banyak kita temui di lapangan masih ada sebagian sekolah-sekolah baik swasta maupun negeri yang belum memiliki kelengkapan Modul Bahan Ajar yang baik dan lengkap, sehingga kita sering mendapati proses belajar mengajar yang menghadapi kendala materi karena ketidak siapan modul bahan ajar, kita juga sering mendapati lulusan yang kurang maksimal kompetensinya karena materi pengajaran yang diterima siswa relatif belum/kurang lengkap dan belum sesuai standar kurikulum.

Ada beberapa maanfaat Modul Bahan Ajar diantaranya : 1) Modul dan penggunaannya bisa membuat pembaca belajar secara mandiri. Tanpa bantuan pendidik 
yang umumnya ada di setiap pembelajaran. Ini menjadikan siswa memiliki keterampilan menggali informasi atau materi dan mengembangkannya dengan mandiri. Jadi tidak selalu bergantung pada guru. 2) Modul disertai metode dan cara melakukan evaluasi. Evaluasi bukan hanya dilakukan pengajar atau guru. Tetapi peserta didik juga bisa melakukan evaluasi pembelajaran dengan modul. Tujuan dari evaluasi supaya mengetahui tolak ukur kemampuan penguasaan materi yang dipelajari sendiri.

Kalau kita melihat kondisi saat ini bahwa tujuan penyusunan Modul Bahan Ajar diantaranya adalah : Memperjelas dan mempermudah penyajian pesan agar tidak terlalu bersifat verbal; Mengatasi keterbatasan waktu, ruang, dan daya indera, baik siswa atau peserta diklat maupun guru/instruktur; Dapat digunakan secara tepat dan bervariasi, seperti : Meningkatkan motivasi dan gairah belajar bagi siswa atau peserta diklat, Mengembangkan kemampuan peserta didik dalam berinteraksi langsung dengan lingkungan dan sumber belajar lainnya,
Memungkinkan siswa atau peserta diklat belajar mandiri sesuai kemampuan dan minatnya, dan memungkinkan siswa atau peserta diklat dapat mengukur atau mengevaluasi sendiri hasil belajarnya.

Secara umum biasanya karakteristik modul bahan ajar dapat diketahui dari formatnya yang disusun atas dasar : 1) Self Instruction, siswa dimungkinkan belajar secara mandiri; 2) Self Contained, seluruh materi termuat dan pembelajaran secara tuntas; 3) Stand Alone, modul tdak tergantung pada bahan ajar lain; 4) Adaptif, modul tersebut dapat menyesuaikan perkembangan ilmu pengetahuan dan teknologi, fleksibel/luwes digunakan diberbagai perangkat keras (hardware); 5) User Friendly (bersahabat/akrab), modul memiliki instruksi dan paparan informasi bersifat sederhana, mudah dimengerti, serta menggunakan istilah yang umum digunakan.

Sedangkan komponen Modul Bahan Ajar diantaranya ada 6 komponen, meliputi : 1) Tujuan Instruksional Eksplisit \& Spesifik, 
artinya modul harus disusun secara eksplisit dan juga spesifik. Tujuan tersebut dirumuskan dalam bentuk tingkah laku. Sehingga diharapkan dapat dipahami lebih mudah dan juga materi yang disampaikan bisa tersampaikan dengan baik secara keseluruhan. 2) Petunjuk Guru, maksudnya adalah bahwa di dalam modul memuat penjelasan untuk guru mengenai pengajaran supaya bisa terlaksana dengan efisien. Modul juga memberikan penjelasan mengenai berbagai macam kegiatan yang dilaksanakan di dalam proses belajar mengajar. Alat-alat, waktu untuk menyelesaikan modul dan sumber pengajaran serta petunjuk evaluasi, semuanya harus ada di dalam modul. 3) Lembar Kerja, maksudnya adalah lembar kerja siswa adalah lembar kerja yang berisi pertanyaan yang terdapat di lembar kegiatan. Lembar ini harus dikerjakan oleh siswa sesudah mereka menguasai materi yang disampaikan. 4) Lembar Kegiatan Siswa, isi di dalam lembar kegiatan siswa berisi tentang materi pelajaran yang harus dikuasai siswa. Selain itu juga dicantumkan buku sumber yang harus dipelajari oleh siswa agar bisa melengkapi materi. 5) Kunci Lembar Kerja, tujuannya agar siswa bisa mengoreksi jawaban mereka sendiri dengan cara menggunakan kunci lembar kerja sesudah berhasil mengerjakan lembar kerja mereka. 6) Lembar Evaluasi, tentunya di dalam lembar evaluasi ini harus ada post test dan juga rating scale. Hasil inilah yang nantinya dijadikan oleh guru di dalam mengukur tercapai atau tidaknya tujuan modul oleh siswa. Selain itu ada juga kunci lembar evaluasi. Tes dan rating scale yang dilengkapi kunci jawaban dalam lembar evaluasi disusun dan dijabarkan dari berbagai rumusan tujuan pada modul.

Untuk menciptakan suasana yang lebih kooperatif dalam implementasi penggunaan Modul bahan Ajar dan agar kerjasama terjalin dengan baik antara guru / tenaga pendidik dengan semua siswa/siswi maka kepala sekolah sebaiknya membuat SOP (Standar Operasional Prosedur) dalam penyusunan Modul bahan Ajar, termasuk di dalamnya mengatur tata cara pelaksanaan distribusi / delivery materi pelajaran oleh semua pendidik 
kepada semua siswa/siswi.

$\begin{array}{cr}\text { Adapun } & \text { Pelaksanaan } \\ \text { Pengabdian kepada masyarakat } \\ \text { (PKM) oleh dosen prodi Sekretari D- }\end{array}$

III Universitas Pamulang yang bertemakan

"Peningkatan

Kompetensi Pendidik Dalam Penyusunan Modul Bahan Ajar di Yayasan Iskandariyah Tangerang

Selatan" ini adalah salah satu wujud dari pelaksanaan Tri Dharma Perguruan Tinggi, dimana pada kesempatan pelaksanaan PKM ini bagi kami merupakan bentuk kepedulian Sekretari D-III Universitas Pamulang untuk berbagi ilmu dan pengalaman dengan masyarakat luas khususnya pada semua tenaga pendidik di sekolahsekolah yang bernaung di bawah Yayasan Iskandariyah Tangerang Selatan agar lebih siap menghadapi perkembangan dunia Pendidikan kedepannya dan lebih kompetitif dan dapat menghasilkan lulusan yang berkualitas unggul dengan cara selalu terus meningkatkan kualitas modul bahan ajar untuk semua materi palajaran, tentunya juga tidak lupa bahwa materi pelajaran selalu diupdate sesuai dengan kebutuhan perkembangan dunia industri/dunia kerja pada umumnya. Selain itu Pengabdian Kepada Masyarakat (PKM) ini diharapkan dapat dimanfaatkan sebagai ajang mengasah kemampuan keilmuan, keterampilan dan kepedulian kami para dosen terhadap lingkungan masyarakat sekitar. Karena memang dosen itu harus terus belajar dan belajar terus serta selalu mengasah kemampuan keilmuannya untuk berbagi ilmu dan pengalaman khusunya kepada seluruh mahasiswa dan umumnya kepada seluruh masyarakat sekitar.

Peserta yang menjadi objek acara Pengabdian Kepada Masyarakat Di Yayasan Iskandariyah Ciputat Tangerang Selatan ini kurang lebih berjumlah 40 (empat puluh) tenaga pendidik yang masih aktif mengajar di sekolah-sekolah yang bernaung di bawah yaysan Iskandariyah. Bentuk pengabdian yang kami lakukan adalah dengan mengadakan workshop kepada semua tenaga pendidik mengenai strategi penyusuna Modul bahan ajar yang baik, lengkap dan komprehenship.

Tentunya harapan kami dengan 
mengadakan kegiatan Pengabdian Kepada Masyarakat (PKM) ini, kami para dosen bisa lebih memahami dan mendapatkan berbagai masukan dari semua stake holder dalam rangka peningkatan kemampuan kami di masa yang akan datang, dimana kami harus selalu siap beradaptasi dengan lingkungan, waktu dan perkembangan ilmu pengetahuan dan teknologi.

\section{METODE PELAKSANAAN}

Berikut merupakan tahapan yang di lakukan, yaitu:

\section{Tahap Persiapan}

a. Survei awal

b. Pemantapan dan penentuan lokasi dan sasaran.

c. Penyusunan bahan atau materi meliputi: slide, infocus, dan fotocopy materi.

\section{Pelaksanaan Kegiatan}

Kegiatan Pengabdian Kepada Masyarakat (PKM) bertempat di Yayasan Iskandariyah Kelurahan Kedaung Kecamatan Pamulang dilaksanakan pada Hari Selasa-Rabu tanggal 14-15 Desember 2021 bertempat di Aula sekolah, Tim PKM dosen prodi Sekretari Universitas Pamulang hadir di lokasi dan acara segera dibuka oleh sambutan Ketua Yayasan Iskandariyah diikuti oleh Sambutan yang dilakukan oleh Edi Junaedi, SE. MM. selaku Ketia Tim PKM, dilanjutkan dengan presentasi oleh Nara sumber Deni Darmawan, S.Sos. M.Pd.I mengenai pentingnya penyusunan Modul Bahan Ajar yang efektif untuk sasaran pengembangkan pembelajaran di masa depan, sedangkan pemaparan yang dilaksanakan dihadapan para guru dan kepala sekolah bertajuk "Peningkatan Kompetensi Pendidik Dalam Penyusunan Modul Bahan Ajar di Yayasan Iskandariyah Tangerang Selatan"

\section{HASIL DAN PEMBAHASAN}

\section{Kendala yang Dihadapi Dalam Penyusunan Bahan Ajar}

Sedikitnya buku ajar di Perguruan Tinggi di Indonesia, ternyata disebabkan oleh kendala-kendala yang sifatnya personal. Hampir sebagian besar penduduk Indonesia 
bisa membaca. Namun, sebagian besarnya merasa kesulitan menulis. Nara sumber dan dosen anggota team pengabdi memberikan bimbingan dan pengarahan untuk memecahkan masalah kendala yang dihadapi dalam penyusunan bahan ajar dengan cara menjelaskan kendala-kendala yang biasanya dihadapi dalam penyusunan bahan ajar, misalnya kendala waktu, maka solusinya adalah tenaga pendidik harus berupaya bisa melakukan manajemen waktu walau di tengah kesibukan harus menyempatkan waktu setiap hari atau setiap minggu untuk menulis bahan ajar. Misalnya lagi ada peserta workshop yang menyampaikan kendala tidak mahir menulis, maka nara sumber mengarahkan dan menyampaikan bahwa menulis modul bahan ajar tidak mutlak harus memiliki kemahiran dalam menulis, tapi menulis itu lebih kepada kebiasaan, ada istilah bisa karea biasa. Kemudian banyak sekali kendala-kendala umum lain yang dihadapi oleh peserta workshop, maka nara sumber dan dosen anggota pengabdi yang lain membimbing dan mengarahkan dengan memberikan contoh-contoh nyata.

\section{Perdebatan Menulis Perlu Bakat}

Sebagian peserta workshop menyampaikan anggapan bahwa menulis memerlukan bakat istimewa. Apalagi jika jenis buku yang ditulis adalah bahan ajar. Maka, anggapan orang yang menulis buku ajar adalah orang-orang jenius dan berbakat. Atas permasalahn ini nara sumber dan dosen anggota pengabdi lain menyampaikan pencerahan dengan memberikan pemahaman kepada mereka bahwa persoalan menulis bahan ajar bukan semata-mata karena bakat, melainkan karena ada kemauan dan niat. Menulis merupakan keterampilan yang bisa dicapai karena proses pembiasaan. Dengan kata lain, menulis dapat dilakukan oleh siapa saja, dan dimana saja. Setiap orang bisa menulis. Setiap orang yang bisa membaca, sudah dipastikan bisa menulis.

\section{Faktor Kesibukan dan Rasa Malas dalam menulis}

Kami anggota team pengabdi menghadapi lagi persoalan yang yang 
disampaikan oleh peserta workshop, yaitu peserta workshop menyampaikan alasan tidak sempat menulis buku karena faktor kesibukan dan rasa malas. Menghadapi persoalan tersebut nara sumber dan dosen anggota team pengabdi lain menyampaikan dan menjelaskan kepada peserta workshop bahwa kesibukan dan rutinitas seperti bom waktu. Pelan, dan mematikan. Kami sampaikan cara manajemen kesibukan. Misalnya dengan membagi waktu kerja. Misal pagi sampai sore jam kerja di kampus, petang dimanfaatkan untuk menulis. Jika malam ada kegiatan lain, bisa disiasati dengan meluangkan waktu satu sampai dua jam untuk menulis.

\section{Mencemaskan Aturan Baku}

\section{Menulis}

Persoalan lain yang kami temukan dari peserta workshop yang menyampaikan adanya kecemasan terhadap aturan baku menulis. Nara sumber dan dosen anggota pengabdi lain menyampaikan dan menjelaskan, betul ini memang masalah klasik yang dihadapi tenaga pendidik ketika akan mulai menulis, dan dapat dikatakan hal ini merupakan hal umum yang dikhawatirkan seorang penulis, mencemaskan aturan baku menulis buku. Banyak penulis pemula, khususnya, yang terpaku dengan aturan dasar. Kecemasan semacam inilah yang secara tidak langsung menghambat penulis untuk memulai. Rasa ketakutan yang melemahkan semangat. Atas persoalan dan kendala ini nara sumber menyampaikan salah satu cara menghindari kecemasan berlebihan yaitu dengan cara mengabaikan. Bagi calon penulis buku ajar langsung menuliskan apa yang ingin di tuliskan. selesaikan semua yang ingin disampaikan hingga akhir. Ketika buku dianggap selesai. Hasil tulisan bisa di baca ulang, dan mulai untuk di koreksi. Selama proses koreksi ulang inilah kita harus memperhatikan masalah EYD yang baik dan benar dan aturan-aturan umum metode penulisan yang benar.

Secara umum dalam proses implementasi workshop itu nara sumber dan kami anggota team pengabdi yang lainnya juga menyampaikan materi diantaranya sebagai berikut : 


\section{Kenapa Harus Membuat}

\section{Modul Bahan Ajar}

Modul Bahan Ajar dibuat sebagai konsekuensi diterapkannya kurikulum tingkat satuan pendidikan berbasis kompetensi di sekolah. Pendekatan kompetensi mempersyaratkan penggunaan modul dalam pelaksanaan pembelajarannya. Modul dapat membantu sekolah dalam mewujudkan pembelajaran yang berkualitas. Penerapan modul dapat mengkondisikan kegiatan pembelajaran lebih terencana dengan baik, mandiri, tuntas dan dengan output yang jelas.

\section{Pengertian Umum Modul}

Modul merupakan bahan ajar yang disusun secara sistematis dengan bahasa yang mudah dipahami oleh siswa, sesuai usia dan tingkat pengetahuan mereka agar mereka dapat belajar secara mandiri dengan bimbingan minimal dari pendidik (Andi Prastowo, 2012: 106). modul merupakan paket program yang disusun dan didesain sedemikian rupa sebagai bahan belajar mandiri untuk membantu siswa menguasai tujuan belajarnya. Oleh karena itu, siswa dapat belajar sesuai dengan kecepatannya masing-masing.

\section{Tujuan Penyusunan Modul}

\section{Bahan Ajar}

a. Memperjelas dan mempermudah penyajian pesan agar tidak terlalu bersifat verbal.

b. Mengatasi keterbatasan waktu, ruang, dan daya indera, baik siswa atau peserta diklat maupun guru/instruktur.

c. Dapat digunakan secara tepat dan bervariasi, seperti :

d. Meningkatkan motivasi dan gairah belajar bagi siswa atau peserta diklat;

e. Mengembangkan kemampuan peserta didik dalam berinteraksi langsung dengan lingkungan dan sumber belajar lainnya,

f. Memungkinkan siswa atau peserta diklat belajar mandiri sesuai kemampuan dan minatnya.

g. Memungkinkan siswa atau peserta diklat dapat mengukur atau mengevaluasi sendiri hasil belajarnya.

\section{Karakteristik Modul Bahan}

Ajar 
Karakteristik modul dapat diketahui dari formatnya yang disusun atas dasar:

a. Self Instruction, siswa dimungkinkan belajar secara mandiri.

b. Self Contained, seluruh materi termuat dan pembelajaran secara tuntas.

c. Stand Alone, modul tdak tergantung pada bahan ajar lain.

d. Adaptif, modul tersebut dapat menyesuaikan perkembangan ilmu pengetahuan dan teknologi, fleksibel/luwes digunakan diberbagai perangkat keras (hardware).

e. User Friendly (bersahabat/akrab), modul memiliki instruksi dan paparan informasi bersifat sederhana, mudah dimengerti, serta menggunakan istilah yang umum digunakan.

\section{Manfaat Modul Bahan Ajar}

a. Menjadi Bahan Ajar Mandiri

Modul dan penggunaannya bisa membuat pembaca belajar secara mandiri. Tanpa bantuan atau keberadaan pendidik yang umumnya ada di setiap pembelajaran.

Ini menjadikan siswa punya keterampilan menggali informasi atau materi dan mengembangkannya dengan mandiri. Jadi tidak bergantung pada guru.

b. Alat Evaluasi

Modul disertai metode dan cara melakukan evaluasi. Evaluasi bukan cuma dilakukan pengajar atau guru. Tetapi peserta didik juga bisa melakukan evaluasi pembelajaran dengan modul. Tujuan dari evaluasi adalah agar tahu tolak ukur kemampuan penguasaan materi yang dipelajari sendiri.

6. Komponen Modul Bahan Ajar

a. Tujuan Instruksional Eksplisit \& Spesifik

Modul harus disusun secara eksplisit dan juga spesifik. Tujuan tersebut dirumuskan dalam bentuk tingkah laku. Sehingga diharapkan dapat dipahami lebih mudah dan juga materi yang disampaikan bisa tersampaikan dengan baik secara keseluruhan.

b. Petunjuk Guru 
Di dalam modul memuat penjelasan untuk guru mengenai pengajaran supaya bisa terlaksana dengan efisien. Modul juga memberikan penjelasan mengenai berbagai macam kegiatan yang dilaksanakan di dalam proses belajar mengajar. Alat-alat, waktu untuk menyelesaikan modul dan sumber pengajaran serta petunjuk evaluasi, semuanya ada di dalam modul.

c. Lembar Kerja

Lembar kerja siswa adalah lembar kerja yang berisi pertanyaan yang terdapat di lembar kegiatan. Lembar ini harus dikerjakan oleh siswa sesudah mereka menguasai materi yang disampaikan.

d. Lembar Kegiatan Siswa

Dalam lembar kegiatan siswa berisi tentang materi pelajaran yang harus dikuasai siswa. Selain itu juga dicantumkan buku sumber yang harus dipelajari oleh siswa agar bisa melengkapi materi.

e. Kunci Lembar Kerja

Siswa bisa mengoreksi jawaban mereka sendiri dengan cara menggunakan kunci lembar kerja sesudah berhasil mengerjakan lembar kerja mereka.

f. Lembar Evaluasi

Di dalam lembar evaluasi terdapat post test dan juga rating scale. Hasil inilah yang nantinya dijadikan oleh guru di dalam mengukur tercapai atau tidaknya tujuan modul oleh siswa. Selain itu ada juga kunci lembar evaluasi. Tes dan rating scale yang dilengkapi kunci jawaban dalam lembar evaluasi disusun dan dijabarkan dari berbagai rumusan tujuan pada modul. 
KESIMPULAN DAN SARAN

Dalam kegiatan PKM yang diadakan di Yayasan Iskandariyah dapat disimpulkan:

1. Kendala umum yang dihadapi tenaga pendidik dalam penyusunan bahan ajar adalah masalah kendala waktu dan kendala belum mahir menulis, untuk kendala-kendala tersebut secara umum pada prinsipnya bisa diatasi dengan manajemnen waktu dan buang pemikiran yang menganggap bahwa menulis itu hanya bisa dilakukan oleh mereka yang sudah mahir. Dengan pelatihan dan membiasakan menulis maka ke depannya tenaga pendidik di Yayasan Iskandariyah akan produktif dalam menghasilkan modul bahan ajar.

2. Masih adanya perdebatan menulis perlu bakat, maka untuk kendala ini para tenaga pendidik sudah mendapatkan pencerahan dari anggota team pengabdi yang menyampaikan bahwa menulis merupakan keterampilan yang bisa dicapai karena proses pembiasaan. Dengan kata lain, menulis dapat dilakukan oleh siapa saja, dan dimana saja. Setiap orang bisa menulis. Setiap orang yang bisa membaca, sudah dipastikan bisa menulis dan tidak memerlukan bakat khusus.

3. Untuk kendala atau masalah faktor kesibukan dan rasa malas dalam menulis, secara umum tenaga pendidik di Yayasan Iskandariyah diarahkan dan diberikan pencerahan dari team anggota pengabdi mengenai bagaimana mengelola waktu dan kesibukan. Nara sumber dan dosen anggota team pengabdi lain menyampaikan dan menjelaskan kepada peserta workshop bahwa kesibukan dan rutinitas seperti bom waktu. Pelan, dan mematikan. Kami sampaikan cara memanajemen kesibukan. Misalnya dengan membagi waktu kerja. Misal pagi sampai sore jam kerja di kampus, petang dimanfaatkan untuk menulis. Jika malam hari sedaang tidak ada kegiatan lain bisa meluangkan waktu satu sampai dua jam untuk menulis.

4. Mengenai persoalan ada sebagian tenaga pendidik yang mencemaskan aturan baku menulis, secara umum tenaga pendidik di Yayasan Iskandariyah sudah cukup memahami penjelasan yang disampaikan oleh nara sumber dan team dosen pengabdi yang menyampaikan salah satu cara menghindari kecemasan berlebihan, dengan cara mengabaikan. Bagi calon penulis buku ajar langsung 
menuliskan apa yang ingin di tuliskan. selesaikan semua yang ingin disampaikan hingga akhir. Ketika buku dianggap selesai. Hasil tulisan bisa di review ulang, dan mulai untuk di koreksi.

\section{DAFTAR PUSTAKA}

Andi Prastowo, 2012: 106, Panduan kreatif membuat bahan ajar inovatif : Menciptakan metode pembelajaran yang menarik dan menyenangkan, Yogyakarta, Diva Press

Dalam pelaksanaan kegiatan PKM ini disarankan:

1. Setelah kami team dosen pengabdi melakukan PKM berupa workshop pelatihan menulis Modul Bahan Ajar di Yayasan Iskandariyah, dapat kami berikan saran kepada Yayasan agar sebaiknya diberikan pelatihan cara menyusun modul bahan ajar secara rutin misalnya setiap semester atau setiap tahun kepada seluruh tenaga pendidik yang ada.

2. Untuk memberikan semangat menulis modul bahan ajar, sebaiknya Yayasan memberikan apresiasi atau reward kepada tenaga pendidik yang berhasil menulis modul bahan ajar dengan kualitas yang baik dan bisa diimplementasikan dalam proses belajar mengajar di kelas.
Departemen Pendidikan Nasional (2002), Teknik Belajar dengan Modul, Jakarta: Dirjen
Pendidikan Dasar dan Menengah

Karya, B. Suryosubroto. (1983) Sistem Pengajaran dengan Modul, Jakarta: Bina Aksara
S. Nasution, (1987) Berbagai Pendekatan Dalam Proses Belajar dan Mengajar, Jakarta:

Bina Aksara

Soeparno. 1988. Media Pengajaran Bahasa. Klaten: Intan Pariwara 